forces in Yugoslavia dedicated to the restoration of the Serbian monarchy after the end of World War II. The book casts significant light on the multiple facets of the conflict between the Chetniks and the partisans. It has been translated into Serbo. Croatian.

Among many honors, Tomasevich was the recipient of the Award for Distinguished Contributions to Slavic Studies from the American Association for the Advancement of Slavic Studies in 1989. He was a master of scholarly skills, a person with bountiful erudition, wit and human dignity.

AltiXander Vuginich

Berkeley, CA

January 1995

\title{
Barbara Jelavich: 1923-1995
}

Barbara Jelavich, Distinguished Professor of History emeritus at Indiana University and honorary member of the Romanian Academy, passed away in Bloomington, Indiana, on 14 January 1995, after a long and courageous battle with cancer. Her life and work as scholar, teacher, mentor, colleague and friend greatly enriched Habsburg, Russian, Ottoman and southeast European studies. Her death diminishes us, but her contributions will inform, guide and inspire for a long time to come.

Born 12 April 1923, Barbara Brightfield earned successive degrees in history from the University of California at Berkeley (an A.B. honors degree in 1943, an M.A. in 1944, and a Ph.D. in 1948). In 1944, she married Charles Jelavich, beginning a deep and exemplary personal and professional partnership that spanned six decades, produced dozens of important studies, and taught two new generations of scholars. Their collaboration was appropriately recognized in 1992 when they were jointly honored with the AAASS Award for Distinguished Contributions to Slavic Studies. (This double distinction is, to date, sui generis.) Perhaps even more significant testimony to their work has been provided by the hundreds of letters her husband has received since Barbara's death from students, peers, and others whose lives and minds were touched and shaped by the Jelaviches.

Barbara Jelavich taught briefly at Berkeley and Mills College, and then devoted her time to raising the Jelaviches' two sons, Mark and Peter, while conducting further research in diplomatic and Balkan history. In 1961, she and her husband came to the Department of History at Indiana University. There, she was promoted to professor in the Department of History in 1967, and named Distinguished Professor of History in 1984. She served as chairman of the Conference on Slavic and East European History (1979) and President of the Society for Romanian Studies (1988-1990). In 1992, when the Jelaviches retired, she was elected an honorary member of the Romanian Academy. That same year, she was given the first Lifetime Achievement Award by the Association for Women in Slavic Studies. Her tireless and conscientious efforts on committees and scholarship bodies on behalf of the profession and the field should also be noted. In 1992, a well deserved festschrift (including their extensive bibliography) was published for Barbara and Charles Jelavich under the editorship of Richard Frucht.

Few people have been so well qualified professionally and personally to work in the unique historical laboratory that is eastern Europe, or have made such significant efforts toward helping the region find its larger place in the world of historical scholarship than Barbara and Charles Jelavich. Working as a team, through travel, research and persistent scholarly effort, they developed a profound, intimate, and empathetic acquaintance not only with the histories, lives, and cultures of the principal Balkan countries (Romania, Bulgaria, Yugoslavia, and Greece), but also with the empires which so deeply influenced their histories (Russian, Austrian, and Ottoman).

Among Barbara Jelavich's many achievements one surely stands out: her ability to make learned scholarship clear and intelligible without sacrificing accuracy or patronizing her audience. Her lectures were graceful models of the true teacher's art, capable of holding the attention of the least committed student and unerringly leading her audience through the most complex thickets of diplomatic contrivance. (I suspect 
that her thorough avocational interest in detection stories contributed to this skillful and sure touch.) Her rigid attention to detail never submerged the main story or displaced rigorous analysis and synthesis. Lucidity, straightforward presentation, and ease of exposition were the primary characteristics of her work.

This integration of first-rate scholarship and top-rank writing is a rarity, as we all know. Barbara Jelavich's ability to combine painstaking archival study, mastery of the primary and secondary sources, and long experience as an outstanding teacher with a first hand acquaintance and a firm grasp of the widely varied pasts and traditions of eastern Europe and its diverse peoples provide the explanation for her success and durability. Small wonder that Barbara Jelavich was, in the words of the prominent Romanian historian Cornelia Bodea, an internationally "respected ruler in her territorial waters."

Her books remain as her monuments, and it will be a long time before her diplomatic histories of the Habsburg and the Russian monarchies, her works on Russia and Romania and Greece, on the diplomacy of the Ottoman Empire, or her history of the Balkans will be superceded. These works, both original monographs and syntheses, emerged from her specialized and often pioneering investigations of much disputed and highly significant problems of nineteenth-century tsarist, Habsburg and Ottoman policy and activity in the Balkans. All reflected the multiplicity of her interests: the Balkans, Russia, great power diplomacy, and expounding the insights provided by original source materials. All reflected her consummate skill as historian and writer. The fact that most of the nearly twenty works that bear her name are still in print reflects their lasting value.

Barbara Jelavich's History of the Balkans (1983) is perhaps her most impressive accomplishment. Undertaken at the request of the Joint Committee on Eastern Europe of the ACLS and the SSRC, it was a characteristic blend of the descriptive/factual and the analytical/synthetic, presented with her typical fluency and no-nonsense clarity. It was an attempt to bring L.S. Stavrianos's pioneering treatment up to date, a task carried out with verve and skill. Her survey not only synthesized the work of the next scholarly generation but also laid the foundation for the next era of maturation in the study of eastern Europe. While the events of 1989 mean that her work, too, will eventually become dated, there is no doubt that it is a landmark achievement that will, like Stavrianos, be read with pleasure and utility long into the future.

Even though Barbara Jelavich retired in 1992 and her physical afflictions became increasingly burdensome, her scholarly work continued. She prepared notes for a revision of her diplomatic history of Russia to take the story through the Gorbachev era. She left behind a chapter intended to update her History of the Balkans through the events of 1989. A Japanese edition of her Modern Austria appeared in 1994. She collaborated on the third edition of the American Historical Association's Guide to Historical Literature (1995). She also completed a forthcoming piece on the international position of Romania in 1848 that reflects the Russian, Habsburg, Ottoman, and southeast European strands of her life's effort. Finally, she continued to work with doctoral candidates, to write letters of recommendation for her students and colleagues, and to share her insights and advice as needed.

"La mort ne surprend point le sage, il est toujours prêt à partir" (La Fontaine). Barbara Jelavich was received into the Catholic Church in 1994; her interment was in the Mission Cemetery in Santa Clara, California. She is survived by her husband, Charles, her sons, Mark and Peter, her grandchildren, and by an international assemblage of students, associates and friends.

It is gratifying to note that a Barbara Jelavich Prize has been established under the auspices of the AAASS to recognize and encourage scholarship in nineteenth-and twentieth-century southeast European and Habsburg studies and in Ottoman and Russian diplomatic history. She would have been pleased to know that in one more way, her influence will live on.

Paul E. Michelson Distinguished Professor of History Huntington College April 1995 